\author{
Fajarsani Retno Palupi \\ Universitas Telkom \\ fajarsanirp@telkomuniversity.ac.id
}

\title{
PENCAPAIAN ADAPTASI IDE PADA KONSEP BENTUK STOOL (Studi Kasus Mata kuliah Mebel I)
}

\begin{abstract}
Abstrak: Mebel merupakan mata kuliah 3 sks yang mendampingi mata kuliah utama, perancangan ruang interior, sebagai pengisi kelengkapan aktivitas penghuni atau user. Pada tahap pembelajaran dasar desain mebel, mahasiswa diharuskan memahami dan mengerti cara untuk mengimplementasi konsep berdasarkan pertimbangan-pertimbangan desain pada bangku atau stool. Desain dapat dikatakan unik ketika ada konsep yang menjadi pembeda dengan benda desain yang telah ada. Cara mendapatkan dan mengolah konsep ada bermacammacam, salah satunya dengan mengadaptasi bentukan ide dan mentransformasikannya dengan cara pandang perancang berdasarkan keilmuan yang valid. Penelitian ini akan berfokus pada analisa hasil desain mahasiswa untuk melihat penerapan pendekatan metafora, implementasi metafora yang intangible, tangible dan kombinasi. Dari beberapa hasil desain yang telah ada mahasiswa telah mampu memahami dan menerapkan pendekatan metafora, adapun penggolongan secara sederhananya dapat dibedakan menjadi 2, yaitu; konsep yang terlihat secara visual dan konsep yang terasa secara persepsi.
\end{abstract}

Kata kunci: konsep, Stool, Metafora

Abstract: The furniture design is courses that accompany the main courses, the design of interior space, as the completeness of the activity of residents or users. On the basic learning stage of furniture design, students are required to understand and know how to implement the concept based on design considerations on bench or stool. The design can be said to be unique when there is the differentiator with designs that have emerged before. How to obtain and cultivate the concept there is a manifold, one of them by adapting the form of ideas and transforming them with designer viewpoints based on valid science. This research will focus on the analysis of the results of design by students to see the application of metaphor, metaphorical implementation that is intangible, tangible and combinations. From existing design can be conclude that the students already understand and applying the approach of metaphor, as for the categorization in simple terms can be distinguished into two, namely; the concept that looks visually and concept that feels by perception of user.

Keyword: Concept, Stool, Metaphor

\section{Pendahuluan}

Pada pembelajaran program studi desain interior, selain mahasiswa diajarkan untuk merancang ruang yang mempertimbangkan aktivitas sebuah ruang untuk kegiatan pengguna ruang baik secara personal maupun penggunaan umum, mahasiswa juga diminta untuk memahami kebutuhan fasilitas mebel pengguna dan merealisasikannya sesuai kebutuhan. Desain interior, Telkom University, memiliki empat level pembelajaran mebel dalam kurikulumnya. Pada level dasar, mebel I, mahasiswa mempelajari mengenai merancang fasilitas sederhana untuk kegiatan duduk, berupa pembuatan bangku atau single seater stool dengan melakukan analisa sederhana dalam mewujudkan kebutuhan fisik dan non-fisik user dalam sebuah stool. Hal ini dilakukan untuk memberikan pemahaman awal terhadap pemikiran mahasiswa mengenai pengemasan ide yang bersifat aplikatif sesuai dengan kasus yang tengah dihadapi. Adaptasi ini diperlukan sebagai bekal guna mempersiapkan mahasiswa menuju tahap pembelajaran selanjutnya yang tingkat kesulitannya semakin meningkat. Ketika semua elemen sudah dipertimbangkan, maka sudah menjadi kewajiban bagi seorang desainer untuk memberikan alternatif rancangan yang akan diajukan kepada client untuk 
dipilih. Dalam proses menghasilkan alternatif, desainer mengembangkan ide pemikirannya, tidak jarang perubahan signifikan masih terjadi pada desain awal.

Mahasiswa mempelajari cara mendapatkan konsep untuk desain bangku dengan memperbanyak perbekalan atau referensi ide dari berbagai hal. Mulai dari referensi gambar sampai dengan mempelajari produk yang sudah ada di pasaran. Mahasiswa melakukan analisa berbagai hal yang berhubungan dengan produk tersebut, misalnya; pemakai produk, segi teknis, sampai dengan adaptasi ide yang diterapkan pada produk bangku. Salah satu ide yang dapat digunakan menjadi konsep desain bangku adalah dengan mengadaptasi bentuk dari hal-hal yang berada di sekitar. Konsep akan diolah dengan pertimbangan beberapa faktor yang mempengaruhi desain. Hal ini akan membuat ide semakin unik dan alternatif-alternatif desain baru diharapkan akan muncul sejalan dengan pemahaman mengenai segi teknisnya. Proses berpikir sampai implementasi ide yang dijalani membutuhkan waktu yang beragam, tergantung pada kerumitan analisa konsep, pemilihan elemen, dan lain sebagainya.

Pada kenyataannya, mayoritas pencapaian konsep dapat dirasakan secara visual maupun nonvisual, baik secara langsung ataupun tidak langsung. Konsep visual juga harus ditunjang dengan segi teknis yang dibutuhkan dalam sebuah desain, dengan mempertimbangkan segi konstruksi yang kokoh dari sebuah stool. Hal inilah yang membuat proses berjalan lebih lama dari yang diharapkan, karena pencapaian bentuk luar desain stool akan terbentur dengan keterbatasan kemampuan material yang digunakan. Material yang dapat digunakan adalah material alami, yaitu kayu, dan boleh dikombinasi dengan material alami lainya, misalnya; rotan, bambu, eceng gondok, dan lain sebagainya. Kayu merupakan bahan dasar mebel yang umum digunakan sebelum adanya revolusi industri dan Indonesia memiliki banyak jenis kayu yang dapat di eksplorasi untuk dipakai dalam pembuatan mebel. Karena masing-masing jenis kayu memiliki karakteristik tersendiri, memerlukan kejelian dalam pengolahan bentuk dan penentuan jenis kayu yang akan digunakan.

\section{Kajian Literatur}

2.1. Desain Mebel Dalam Pendidikan

Wardani (2004) menjelaskan bahwa desain merupakan kegiatan pemecahan permasalahan dan menghasilkan inovasi yang bertujuan untuk mendapatkan solusi yang optimal disesuaikan dengan mengolah gagasan ke dalam sebuah model dan merealisasikannya dengan menambahkan nilai kreativitas, dan pemecahan permasalahan yang berlaku untuk satu khusus belum tentu berlaku pula untuk kasus lainnya. Menghasilkan desain yang baik tidak hanya mencakup bentuk akhir, bahan dan warna mebel/ furniture saja, akan tetapi mempertimbangkan fungsi yang dapat menjadi solusi kebutuhan sosial penggunanya. Pertimbangan selanjutnya termasuk juga mengenai reproduksi, ketahanan, konstruksi, efisiensi penggunaan material, ergonomi, penggunaan teknologi dibandingkan hanya mempertimbangkan masalah estetika dan kenyamanan pribadi. Desain yang baik dapat dikategorikan sebagai berikut (Buchori dalam Wardani, 2004):

- Faktor performansi, meliputi kenyamanan, segi kepraktisan, keselamatan, kemudahan dalam operasional, kemudahan dalam pemeliharaan,

- Faktor fungsi, kelayakan digunakan, dapat diandalkan, struktur, spesifikasi material,

- Faktor produksi, desain harus dapat diproduksi dengan sistem yang telah ada, atau sistem baru yang memungkinkan digunakan, 
- Faktor pemasaran, selera pasar, citra produk, sasaran pasar, harga pasaran, dan saluran distribusi,

- Kepentingan produsen, status dan identitas produsen,

- Kualitas bentuk, gaya yang diadopsi, daya tarik visual ataupun non-visual, citra produk, nilai keindahan, finishing, kombinasi material, pertimbangan keselarasan struktur dan bentuk yang digunakan.

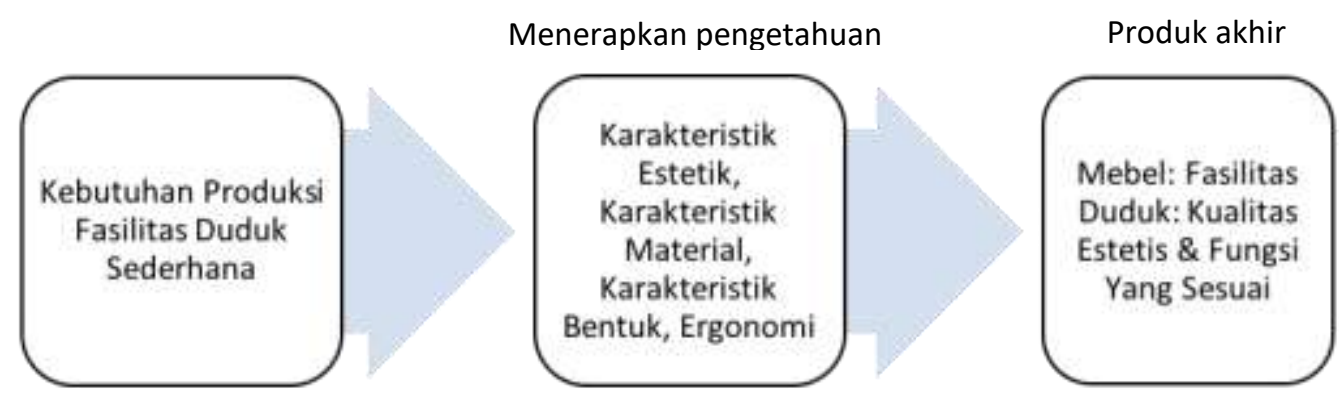

Gambar 1. Capaian Proses Pengajaran Mebel I

(Sumber: Dikembangkan Dari Wardani, 2004)

Dalam pengajaran desain mebel, dimulai dari tingkat dasar beberapa prinsip ini sudah dijadikan pertimbangan desain agar desain yang dihasilkan tepat sasaran, salah satu hal yang belum menjadi pertimbangan secara khusus adalah faktor pemasaran, dikarenakan pada level dasar pencapaian fungsi yang didukung oleh pertimbangan user atau ide bentuk yang diutamakan untuk dipahami oleh mahasiswa. Kurikulum mebel I di Universitas Telkom sudah memasukkan pertimbangan ergonomi, sebagai dasar untuk menentukan ukuran mebel yang layak digunakan, nyaman dan aman bagi pengguna mebel.

\subsection{Metafora Dalam Desain}

Pendekatan metafora pada keilmuan desain sudah banyak digunakan secara umum dan dapat terlihat dari banyaknya desain yang tercipta. Pendekatan ini menjembatani ide/ konsep yang diusung desainer, bagaimana proses berpikirnya dan bagaimana produk itu akan disajikan pada user. Obyek desain merupakan sebuah karya pemikiran dari desainer, dalam proses kreasinya diperlukan pemahaman ide / konsep yang diaplikasikan untuk hasil desain yang optimal. Pemahaman obyek dalam pendekatan metafora terdiri dari (Hekkert \& Cila dalam Bae, 2012):

1. Identifikasi secara fisik,

2. Ideologi tertentu yang digunakan,

3. Makna simbolis,

4. Kegunaan atau fungsinya,

5. Pesan tersirat ataupun terlihat, dsb. 

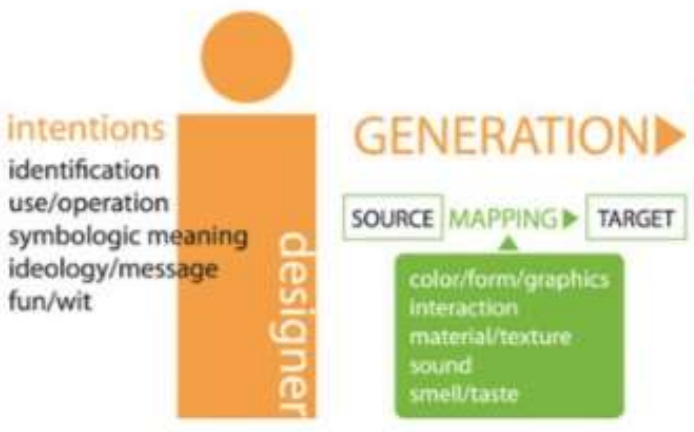

Gambar 2. Dasar Pendekatan Metafora Dalam Desain

(Sumber: Hekkert \& Cila, dalam Bae, 2012)

Desainer harus paham betul mengenai konten pengguna, mengenai bagaimana produk tersebut dirasakan oleh user (Bushe dalam Bae, 2012). Pengalaman pengguna dapat tercipta dari adanya; observasi, pemikiran, perasaan, keinginan. Dalam perwujudan desain dari adaptasi ide peran desainer itu sangat besar untuk membuat pengguna paham dan familiar dengan desain. Desainer juga bertugas untuk menentukan atribut yang akan diterapkan pada desainnya, seperti bentuk, warna dan materialnya. Media / material yang digunakan untuk merealisasikan ide memegang peranan penting dalam membentuk persepsi terhadap produk desain.

\subsection{Atribut Metafora}

Antoniades dalam Katoppo dan Melissa (2012) menjelaskan konsep atau ide dalam metafora dapat dibagi menjadi 3: (1)Intangible metaphor, adaptasi sebuah konsep, sebuah ide, kondisi tertentu ; (2)Tangible Metaphor, adaptasi ide dengan mempertimbangkan karakteristik visual atau materialnya; (3)Combined Metaphor merupakan penggabungan antara konseptual dan visualisasi. Pada kenyataannya, yang sering digunakan dalam desain adalah tangible metaphor, dikarenakan pencapaian desain yang lebih mudah dipahami dan dikenali oleh user dibandingkan dengan pendekatan ide lainnya.

"Furthermore Lakoff and Johnson called their system of metaphor as conceptual construction, which they divide into 2 main aspects: (1) Source domain as the metaphor itself, or the representation of the thing itself, simply put as the concrete form; and (2) Target domain as something that worked and should be understood behind the metaphor, simply put as the abstraction." (dalam Katoppo dan Melissa, 2012)
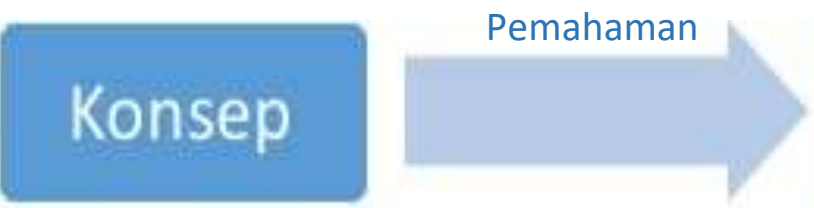

\section{Implementasi}

Gambar 3. Proses Metafora Dalam Desain

(Sumber: Wulff et.al dalam Bae, 2012) 
Secara sederhana dapat dipahami bahwa bentuk akhir yang diaplikasikan atau diterapkan pada desain dengan pendekatan metafora mewajibkan adanya pemahaman mengenai halhal yang terlihat secara visual ataupun yang tidak terlihat. Hal-hal yang dapat terlihat biasanya mudah dalam penyampaian ide atau maksud perancang, sedangkan hal-hal yang bersifat intrinsik perlu penjelasan lebih karena hal-hal yang bersifat konotasi tidak selalu dipahami sama oleh sebagian orang. Untuk menjembatani hal tersebut diperlukan "pengantar karya" dapat berupa apapun, akan tetapi yang paling mudah biasanya adalah judul karya, walaupun ada juga yang menyertakan portofolio karya. Dari beberapa hal yang telah dijelaskan sebelumnya metafora memiliki atribut untuk mempermudah dalam pemahamannya, hal tersebut dapat dijelaskan sebagai berikut:

\section{- Referensi}

Menghasilkan ide desain dengan memberikan kebaruan untuk memperlihatkan nilai keunikan desain tidak selalu dengan menghasilkan pemikiran atau benda yang benarbenar baru atau yang belum pernah ada sama sekali, keunikan atau kreativitas desain dapat diperoleh dengan merujuk pada benda atau sesuatu yang ada di sekitar dengan memberikan pembeda dari proses berpikir, pengambilan ide dari sebuah obyek, atau hasil yang diharapkan meskipun memiliki ide dasar yang sama. Desainer dapat mengkomunikasikan pemahaman terhadap sebuah ide / konsep melalui atribut desain untuk memperlihatkan apa yang desainer ingin user rasakan.

\section{- Korelasi}

Inti dari komunikasi pada sistem metafora berdasar dari korelasi. Sering kali ketika indra manusia melihat sesuatu untuk mempermudah dalam pemahaman, manusia akan mendeskripsikannya dengan "mirip seperti" atau "terasa seperti", hal ini akan mempermudah orang lain untuk memahami konteks.

\section{- Kognitif}

Sebuah produk harus dapat mengkomunikasikan fungsinya secara jelas serta bagaimana cara perlakuan / cara penggunaan / cara operasional yang benar dengan memahami obyek secara visual ataupun non-visual.

\section{- Retorika}

Dalam mengkomunikasikan desain, akan lebih menarik jika mempertimbangkan pula penambahan ekspresi ide atau konsep, dengan hal tersebut akan memberikan makna yang lebih mendalam pada produk desain dan mampu menciptakan keterikatan emosional antara user dan obyek desain.

\section{Metode Penelitian}

Penelitian ini merupakan penelitian deskriptif eksploratif, menggunakan basis data teoritis dan observasi di dalam kelas, serta analisa hasil dari perancangan mebel. Sample mahasiswa dipilih secara purposive sampling, 9 sample tugas besar mahasiswa desain mebel 1, dengan asumsi bahwa sampling sudah berhasil dalam pencapaian konsep, indikator keberhasilan pencapaian performansi desain menurut Buchori (dalam Wardani, 2004), menjelaskan bahwa desain haruslah nyaman, aman, praktis, mudah dalam operasional, dan juga mudah dalam perawatan maupun perbaikannya. 


\section{Hasil/Temuan}

Pada mata kuliah Desain Mebel I, penekanan capaian pembelajaran untuk mahasiswa adalah agar mahasiswa memahami dasar-dasar perancangan fasilitas duduk sederhana, berupa bangku/ stool. Mahasiswa dilatih tidak hanya mampu membuat bangku yang ergonomis untuk pengguna namun juga mampu menghasilkan desain yang original. Proses pengolahan konsep berlangsung berulang-ulang, mengingat harus adanya penyesuaian dengan material yang disyaratkan wajib untuk digunakan, yaitu kayu solid. Awal proses mahasiswa menentukan ide yang akan diusung, dengan mengolah bentuk-bentuk dengan menghasilkan beberapa alternatif yang kemudian akan disaring menjadi hanya 2 alternatif untuk dikembangkan kemudian. Permasalahan berikutnya yang menimbulkan perubahan bentuk adalah jenis material yang diusulkan terkadang tidak memiliki spesifikasi yang diharapkan, sehingga masih terjadi penyesuaian kembali. Adapun proses yang dilalui dapat dijelaskan melalui diagram dibawah ini:

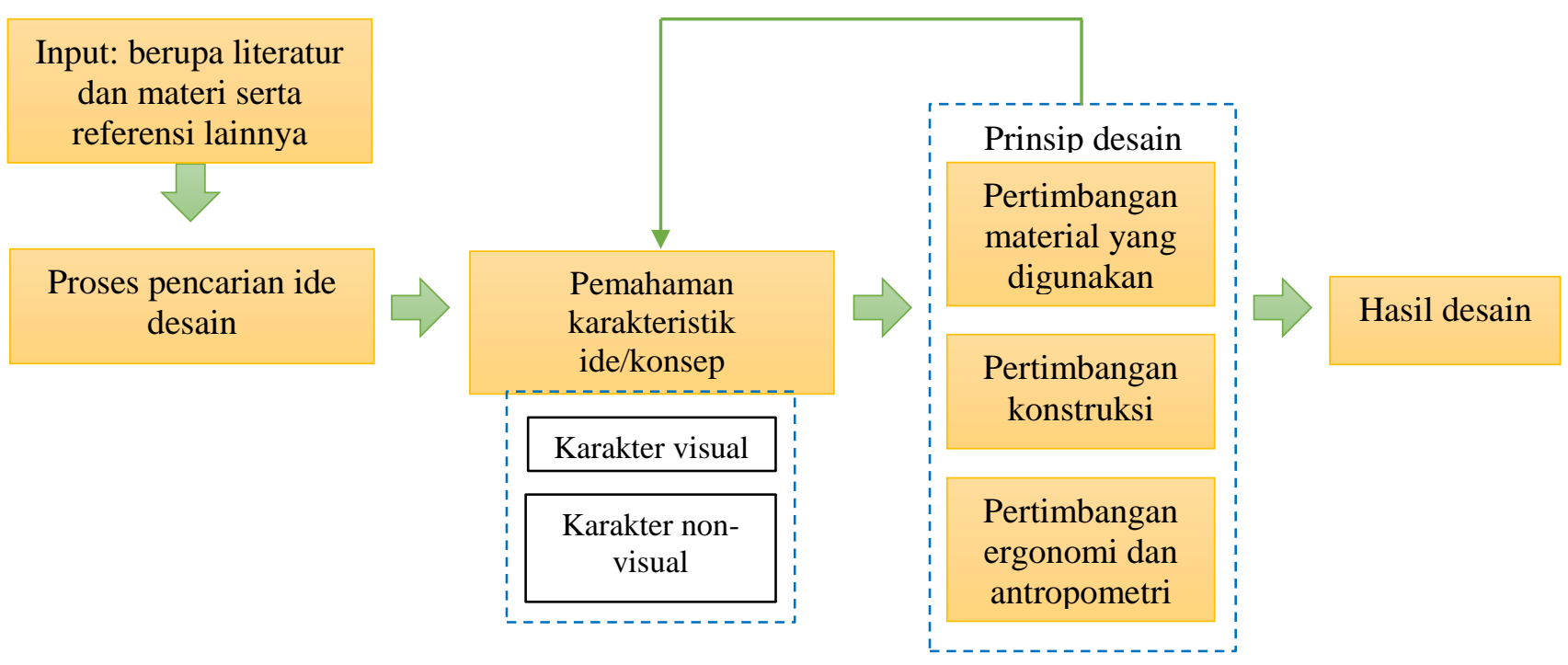

Gambar 4. Kerangka Berpikir Pendekatan Metafora Mata Kuliah Desain Mebel I, Universitas Telkom

Seperti yang telah dijelaskan sebelumnya, bahwa konsepsi pendekatan metafora memiliki 3 penggolongan, intangible, tangible dan kombinasi. Perwujudan konsep yang apa adanya, perwujudan konsep yang menggunakan pemahaman sifat atau nilai simbolik, serta penggabungan keduanya. Dari hasil desain mahasiswa dapat di analisa bahwa masing-masing penggolongan memiliki pesertanya masing-masing. Pertimbangan desain dari masing-masing konsep terhubung juga dengan kemudahan maintanance karena desain yang baik itu tidak hanya indah dilihat, tetapi nyaman digunakan dan juga mudah dalam perawatan dari kerusakan atau pembersihan berkala. Pada level dasar pembelajaran desain mebel, mahasiswa menggunakan material kayu solid sebagai bahan utama, sehingga diwajibkan untuk memahami karakteristik material. Dari beberapa jenis kayu solid pun memiliki spesifikasi yang harus disesuaikan dengan konsep, bagaimana material juga mendukung visualisasi tertentu, misalnya terkesan kokoh, terkesan ringan, terkesan lembut, dan lain sebagainya. Jenis kayu solid yang masih menjadi pilihan favorit mahasiswa di antaranya adalah: kayu jati, kayu mahoni, kayu pinus, dan lain sebagainya. 
Tantangan berikutnya adalah menyatukan bentukan luar dan konstruksi, dikarenakan setiap material memiliki keterbatasan pengolahan termasuk juga kayu solid, sifat dasar kayu yang statis, menghasilkan desain yang kokoh, tegas, dan kaku, walaupun secara teknologi kayu sekarang bisa di bending, akan tetapi proses ini memiliki konsekuensi ekonomis, serta jenis kayu tertentu saja yang dapat digunakan. Dalam prosesnya, dapat dipelajari banyak hal, seperti; (1) Penyampaian ide akan lebih optimal jika seluruh elemen memiliki peran untuk "membangun" tercapainya konsep, (2) Penentuan elemen utama, elemen pendukung, dan elemen estetis, karena jika semua elemen itu "vocal" maka desain tersebut akan menjadi berlebihan, (3) Struktur/ konstruksi harus efektif, semakin banyak bagian/ sambungan, semakin ringkih ketika menerima adanya gaya gerak kegiatan duduk, (4) Desain yang aman dan nyaman merupakan desain yang fit in dengan lingkungannya.

Dari tabel di bawah didapatkan data bahwa perancang memahami ide yang selanjutnya terimplikasi dalam desain dengan memahami ciri khas secara visual atau pembungkus luar. Perancang menangkap karakteristik utama dari masing-masing ide, dengan hal tersebut hasil desain lebih mudah untuk dikenali ide dasarnya. Selain cover, perancang juga memahami sistem atau nilai simbolik atau nilai intrinsik dari ide, sistem spesifik memberikan pengalaman baru pada sistem yang ada pada desain stool. 


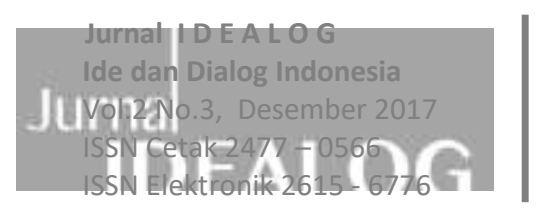

Tabel 1. Capaian Desain Pendekatan Metafora Pada Mata Kuliah Desain Mebel I, Universitas Telkom

HASIL DESAIN

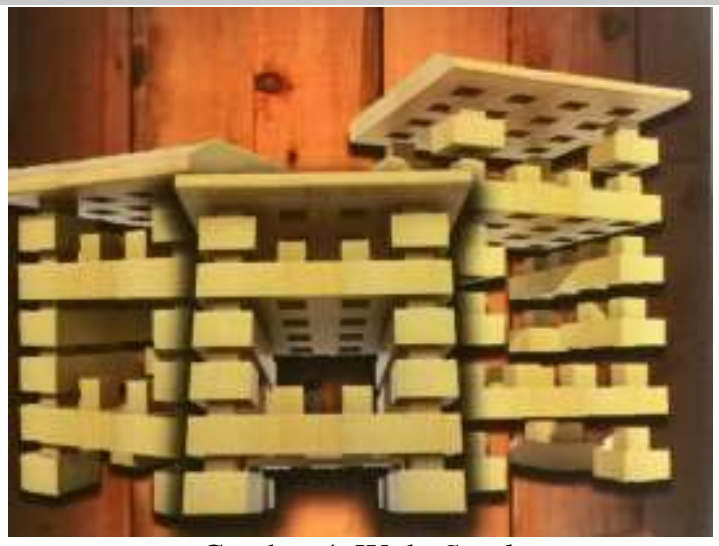

Gambar 4. Wole Stool

Sumber: Tugas Mahasiswa an. Tasmin, 2013

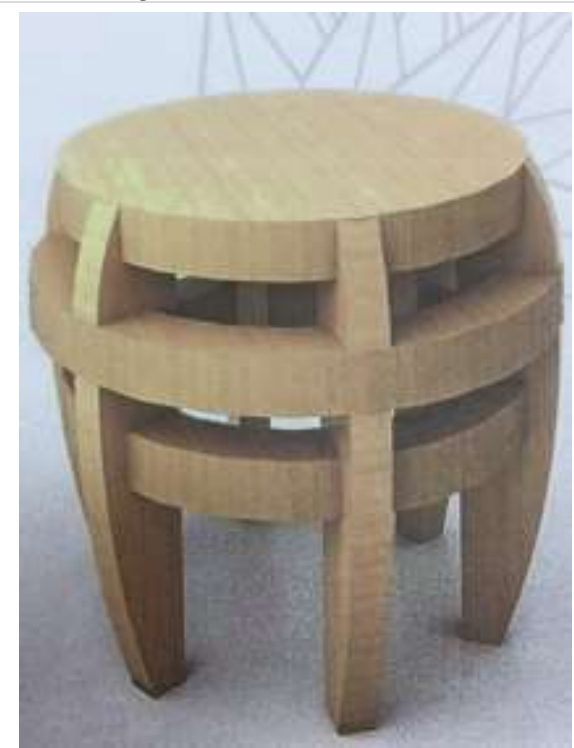

Gambar 5. Bumble Rings Stool

Sumber: Tugas Mahasiswa an. Ash-Shidiqq, 2013

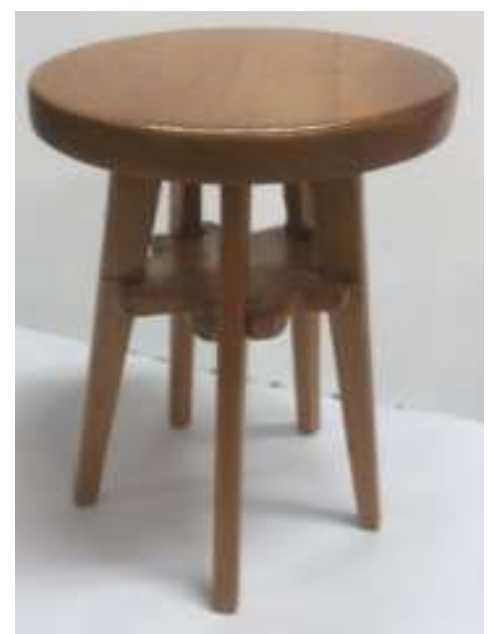

Gambar 6. Starlight Stool

Sumber: Tugas Mahasiswa an. Ash Shiddiq, 2017
INSPIRASI

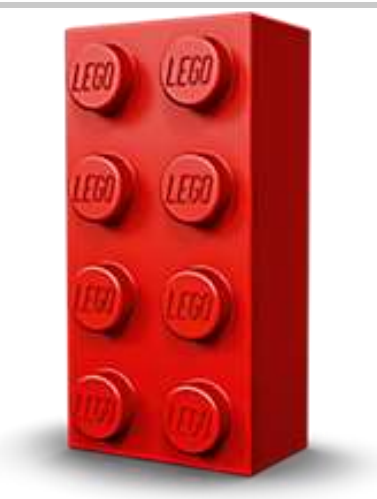

Sumber:https://shop.lego.com/enGB/Individual-Bricks: 16 maret 2018

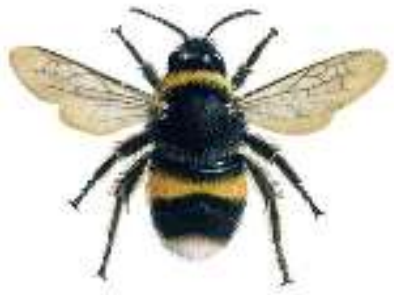

Sumber: https://www.rspb.org.uk/birdsand-wildlife/wildlife-guides/other-gardenwildlife/insects-and-other-

invertebrates/bees-wasps-ants/bumblebee/: 16 Maret 18

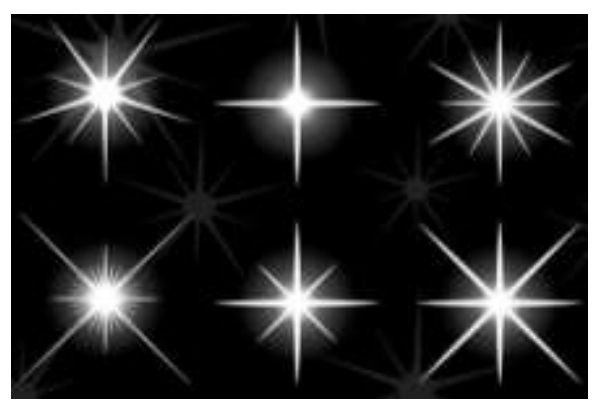

Sumber:https://www.vecteezy.com/vectorart/102906-bright-star-lights: 16 Maret 18
DESKRIPSI

Terinspirasi dari bentukan dan sistem operasional dari permainan lego, stool ini pun dapat bongkarpasang menjadi 18 bagian penyusun.

Terinspirasi dari abdomen bumble bee, yang terbagibagi dengan beberapa bagian. Pemilihan jumlah kaki stool juga disesuaikan dengan jumlah kaki lebah ini, karakteristik kaki stool dibuat ramping dan melengkung.

Di sini mahasiswa menerapkan jumlah penyederhanaan dari cahaya bintang. Pada bentukan konstruksi penyangga antar kaki-kaki stool. Bagian kaki dari atas kebawa memiliki ukuran kaki yang semakin kecil. 


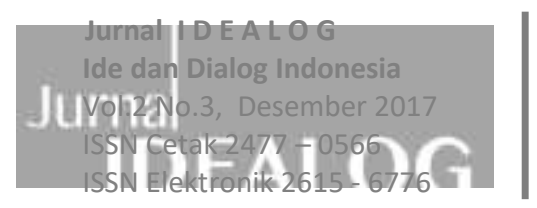

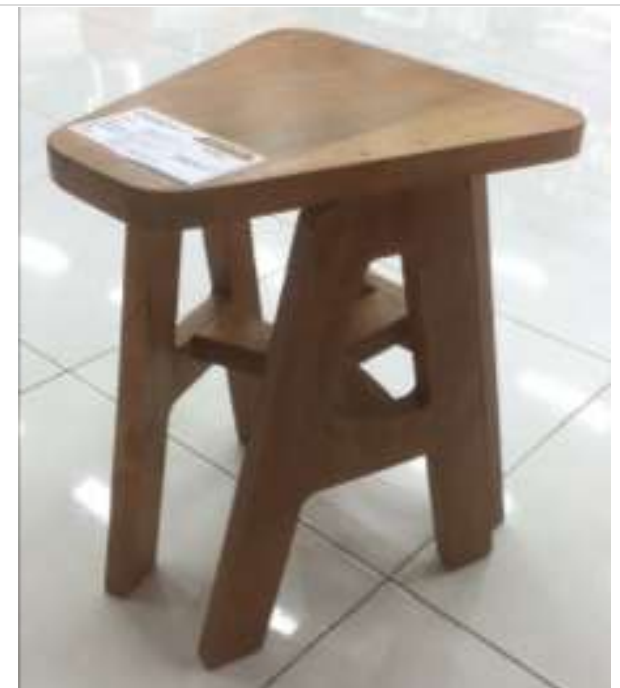

Gambar 7. A Stool

Sumber: Tugas Mahasiswa an. Budiman, 2017

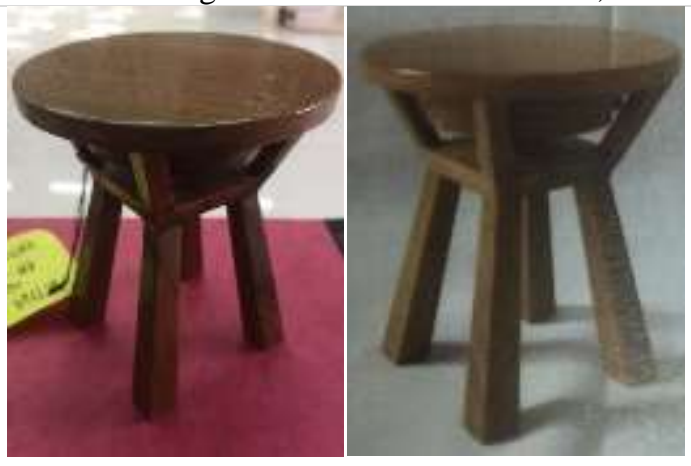

Gambar 8. Gendang Stool

Sumber: Tugas Mahasiswa an. Trisartika, 2017

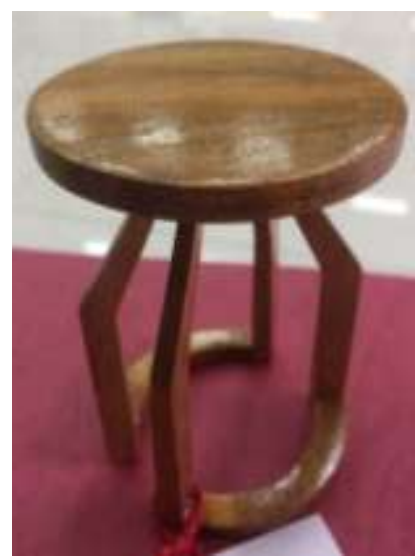

Gambar 9. Lidah Mertua Stool

Sumber: Tugas Mahasiswa an. Rahmawati, 2017
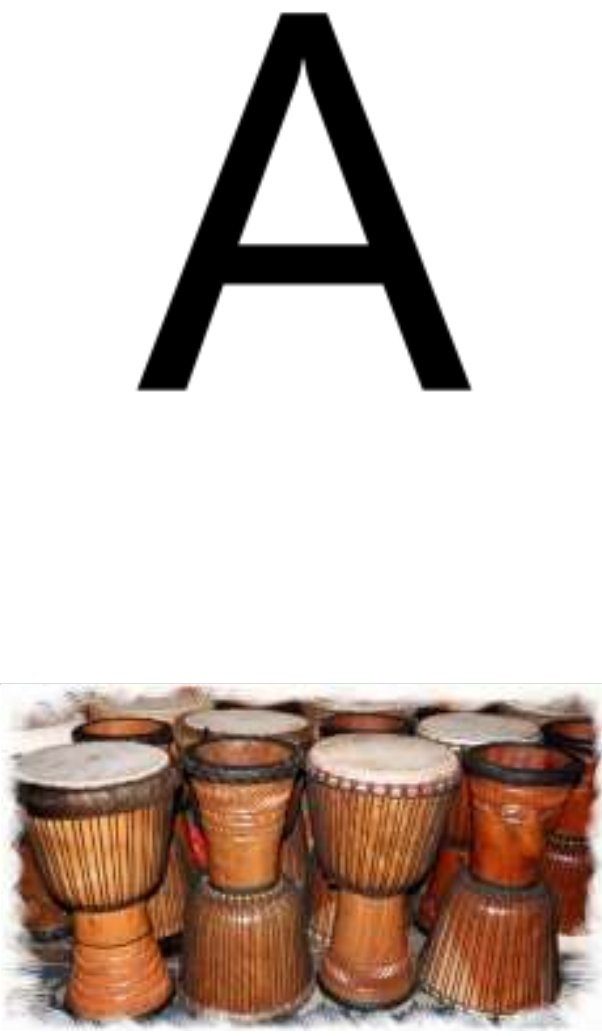

Sumber:

https://belitar.com/product/kendang-jimbeblitar/ : 16 Maret 18

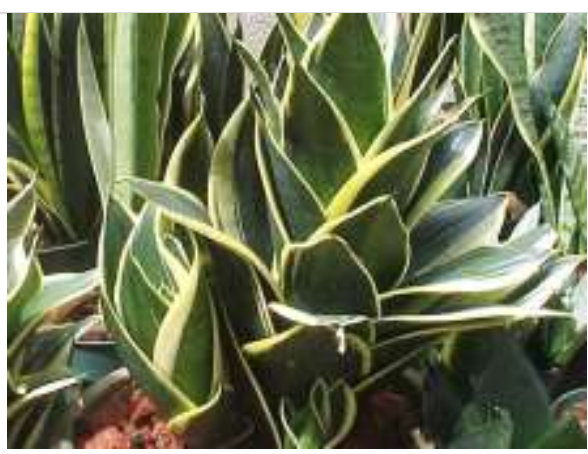

Sumber:

http://www.kinisehat.com/2016/04/manfaatdaun-lidah-mertua-menakjubkan.html : 16 Maret 18
Terinsirasi dari huruf A, dan ketertarikannya dengan bentuk segitiga yang menjadi outline huruf A.

Perancang menggunakan pengolahan huruf A sebagai kaki stool, dan sebagai penghubung antar kakinya perancang mengambil prinsip titik tengah sisisisi segitiga.

Terinspirasi dari bentuk kendang, mengambil outline luarnya, serta segmen dari kendang.

Terinspirasi dari susunan tanaman lidah mertua yang saling meliuk. 


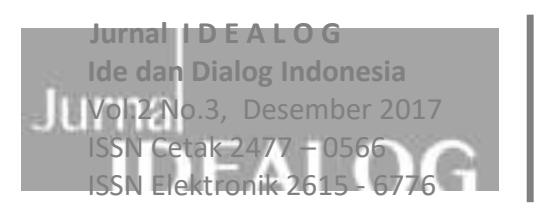

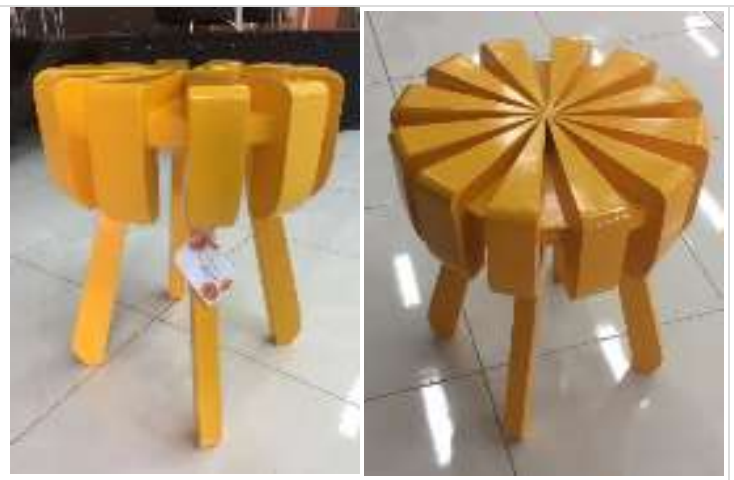

Gambar 10. Pumpkin Stool

Sumber: Tugas Mahasiswa an. Apridayani, 2017

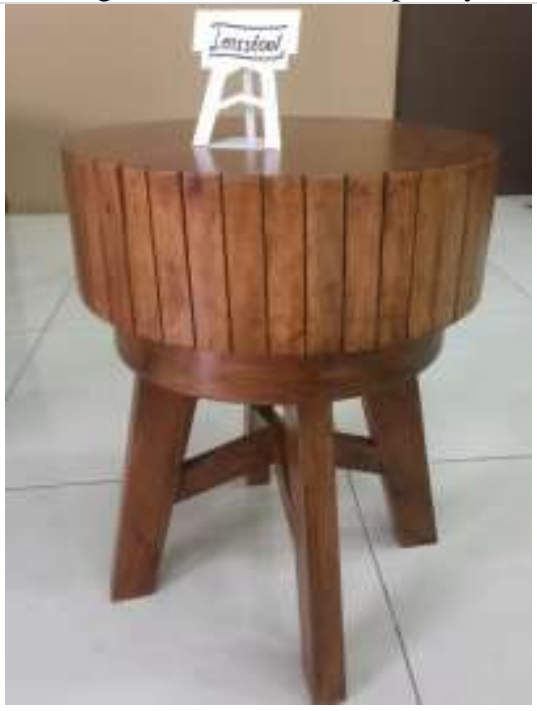

Gambar 11. Lens Stool

Sumber: Tugas Mahasiswa an. Wafi, 2017

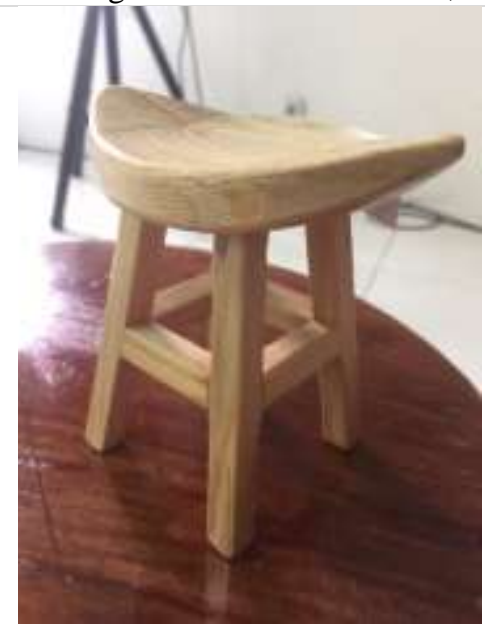

Gambar 12. Tanduk Kerbau Stool

Sumber: Tugas Mahasiswa an. Tsani, 2017

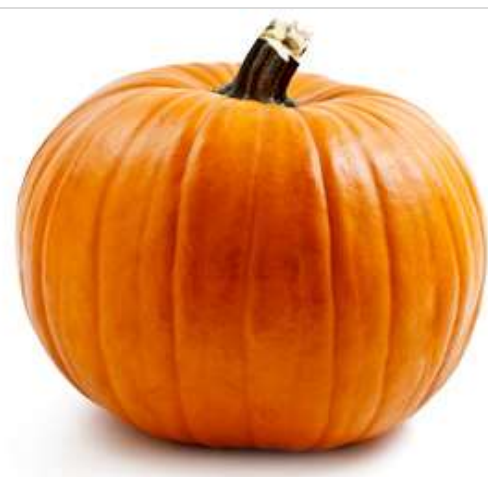

Sumber: http://www.kineticsnj.com/foodweek-pumpkin/: 16 Maret 18

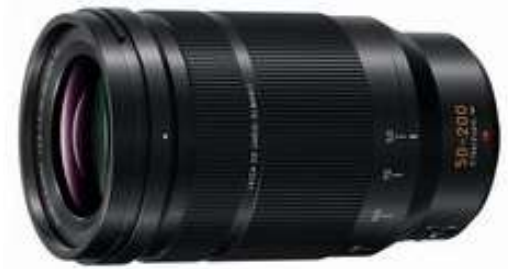

Sumber:

http://shop.panasonic.com/cameras-andcamcorders/lumix-camera-lenses : 16 Maret 18

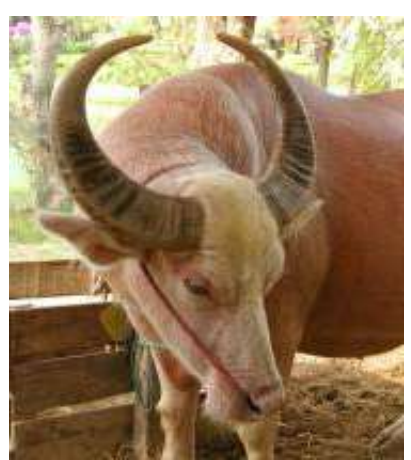

Sumber: http://tourtoraja.com/kerbaudalam-tradisi-toraja.html/ : 16 Maret 18
Terinsiprasi dari pumpkin,

perancang

mengimplementasi

kan warna,

segmen

permukaan, dan karakter bentukan curve.

Terinspirasi dari sistem dan bentukan lensa kamera, alas duduk stool ini juga dapat diputar mengikuti sistem pengambilan fokus gambar pada lensa kamera.

Terinspirasi dari bentukan tanduk kerbau, aplikasinya ada pada alas duduk bangku, dan perancang juga mempertimbangkan pemilihan warna finishing untuk mendukung konsepnya.

\section{Kesimpulan}

Sebagai salah satu pendekatan perancangan mebel, metafora menghasilkan desain yang beragam, sesuai dengan pemahaman perancangnya. Pendekatan metafora lebih mudah di 
tangkap maksud dan tujuannya ketika perancang jeli melihat karakteristik spesifik yang hanya dimiliki oleh referensi ide tersebut, untuk mempermudah identifikasi, perancang mewujudkannya melalui: penggunaan warna, transformasi karakteristik bentuk, sistem operasional/ sistem konstruksinya, tekstur, karakteristik material. Mayoritas sampling yang di analisa melihat karakteristik visual sebagai modal utama perancangan mebelnya, sedangkan hal yang bersifat intrinsik seperti nilai sifat, nilai simbolis, masih belum secara optimal untuk diaplikasikan pada hasil desain, hal ini dapat menambah ketertarikan secara emosional, dan memberikan persepsi visual yang berbeda terhadap hasil desain.

\section{Daftar Pustaka}

[1] Bae, Yongsun. Design Through Metaphor, Master's Programme in Industrial and Strategic Design Aalto University School of Arts, Design and Architecture, (2012). Tavsan, Filiz \&

[2] Katoppo, Martin L \& Melissa, Cindy. Metaphor Identifier: A tool or parameter to identify and measure value in interior design projects, Symposium 2012 Interior: a state of becoming, September 2012, Curtin University, (2012).

[3] Kövecses, Zoltán et. al. Metaphor: A Practical Introduction, Oxford University Press, New York, (2010).

[4] Sonmez, Elif. Biomimicry in Furniture Design, Procedia - Social and Behavioral Sciences 197 (2015) 2285 - 2292, 05-07 February 2015, Novotel Athens Convention Center, Athens, Greece, (2015).

[5] Wardani, Laksmi Kusuma, Desain Mebel Dalam Pendidikan Seni Dan Desain, Dimensi Interior, Vol. 2, No. 2, (2004): $134-146$. 